\title{
Flowering Time in Watermelon Is Associated with a Major Quantitative Trait Locus on Chromosome 3
}

\author{
Cecilia E. McGregor ${ }^{1}$ \\ Department of Horticulture and Institute of Plant Breeding, Genetics and Genomics, University of \\ Georgia, 1111 Miller Plant Sciences, Athens, GA 30602 \\ Vickie Waters and Tripti Vashisth \\ Department of Horticulture, University of Georgia, 1111 Miller Plant Sciences, Athens, GA 30602
}

\author{
Hussein Abdel-Haleem \\ Institute of Plant Breeding, Genetics and Genomics, University of Georgia, 111 Riverbend Road, \\ Athens, GA 30602
}

\begin{abstract}
AdDITIONAL INDEX wORDS. flowering locus $T$, tempranillo 1 , heritability
ABSTRACT. U.S. watermelon (Citrullus lanatus) production is worth $\approx \$ 0.5$ billion annually to growers and nearly all of them are dependent on reliable synchronized flowering time of triploid cultivars and diploid pollenizers in their production fields. One aspect of this synchronization is time to flowering, the change from the vegetative to reproductive phase of a plant. Flowering time has emerged as one of the key traits in horticultural and agronomic crops to breed for escape from biotic and abiotic stresses. However, very little is known about the control of flowering time in watermelon. The number of genes involved, mode of inheritance, heritability, and the possible candidate genes are all unknown. In this study, quantitative trait loci (QTL) associated with days to first male flower (DMF), days to first female flower (DFF), and the female-male flower interval (FMI) were identified in a 'Klondike Black Seeded' $\times$ 'New Hampshire Midget' recombinant inbred line population over 2 years. Heritability for DMF, DFF, and FMI were $0.43,0.23$, and 0.10 , respectively. Control of flowering time was oligogenic with a major, stable, colocalized QTL on chromosome 3 responsible for $\approx 50 \%$ of the phenotypic variation observed for DMF and DFF. This region of the draft genome sequence contains 172 genes, including homologs of the flowering locus $\mathrm{T}$ (Cla009504) and tempranillo 1 (Cla000855) genes associated with flowering time in other species. $\mathrm{Cla009504}$ and $\mathrm{Cla000855}$ represent excellent candidate genes toward the development of a functional marker for marker-assisted selection of flowering time in watermelon. In addition to the major QTL on chromosome 3, two other QTL were identified for DMF (chromosomes 2 and 3) and DFF (chromosomes 3 and 11) and one for FMI on chromosome 2. Understanding the genes involved in this trait and the ability to select efficiently for flowering time phenotypes is expected to accelerate the development of new watermelon cultivars in changing environmental conditions.
\end{abstract}

The change from the vegetative to the reproductive phase of a plant is an important aspect in most commercial agronomic and horticultural crops. A shorter production cycle often means lower input costs for the producer and less environmental impact through energy-saving and reduced pesticide use. A short production cycle also allows for escape from pathogens by harvesting crops before environmental conditions are favorable for high disease pressure (Poland et al., 2009). Flowering time is thus often used to avoid biotic and abiotic stresses. The time to first male and female flower and the interval between the appearance of male and female flowers in monoecious plants have also emerged as key traits used to breed for increased yield under drought conditions (Bolaños and Edmeades, 1993; Chapman and Edmeades, 1999; Richards, 2006; Siddique et al., 1990). The association of drought quantitative trait loci and flowering time loci (Ducrocq et al., 2008) and the realization that selection for specific flowering phenotypes increases yield under drought conditions have contributed to flowering time traits emerging as key breeding priorities for the future (Jung and Müller, 2009).

Flowering traits are complex and it is anticipated that climate change will greatly influence flowering (Craufurd and

Received for publication 6 Nov. 2013. Accepted for publication 4 Dec. 2013. We thank Jeremy Ray, Allen Ray, Dusty Martin, and Will Groover for their contributions to this research.

${ }^{1}$ Corresponding author. E-mail: cmcgre1@uga.edu.
Wheeler, 2009). As can be expected for such an important trait, a large amount of research has been carried out and the genetic architecture and molecular pathways for flowering time are well described for model systems such as Arabidopsis thaliana and are becoming clearer for important agronomic crops (for recent reviews, see Buckler et al., 2009; Jackson, 2009; Matsoukas et al., 2012; Turck et al., 2008). The picture that is emerging from $A$. thaliana shows that the molecular pathways that control flowering include a large number of genes representing photoperiod (light signaling and circadian clock), vernalization, autonomous signals, and gibberellin biosynthesis. Very briefly, in the leaf constans [CO (Valverde et al., 2004)] transcription is up-regulated in response to signals received from the photoperiodic induction pathway. The accumulation of $C O$ protein activates flowering locus $T$ [FT (Kardailsky et al., 1999; Kobayashi et al., 1999; Valverde et al., 2004)], which is a floral inducer. $F T$ can also be induced through a $C O$ - independent pathway where $F T$ suppressors are down-regulated. After moving to the meristem, the $F T$ protein promotes other pathway integrator genes (Lee et al., 2008; Liu et al., 2008; Yoo et al., 2005), which affect floral meristem identity genes, leading to flowering (Abe et al., 2005; Lee et al., 2008; Melzer et al., 2008; Wigge et al., 2005).

Watermelon production is responsible for $\approx 7 \%$ of world vegetable production acreage (Food and Agriculture Organization of the United Nations, 2011). However, very little is 
(A)

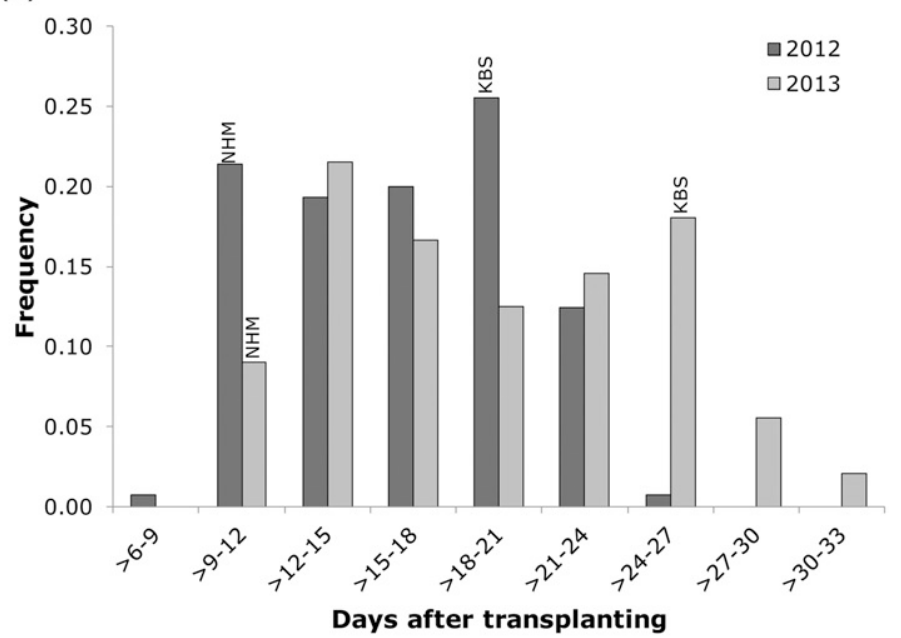

(B)

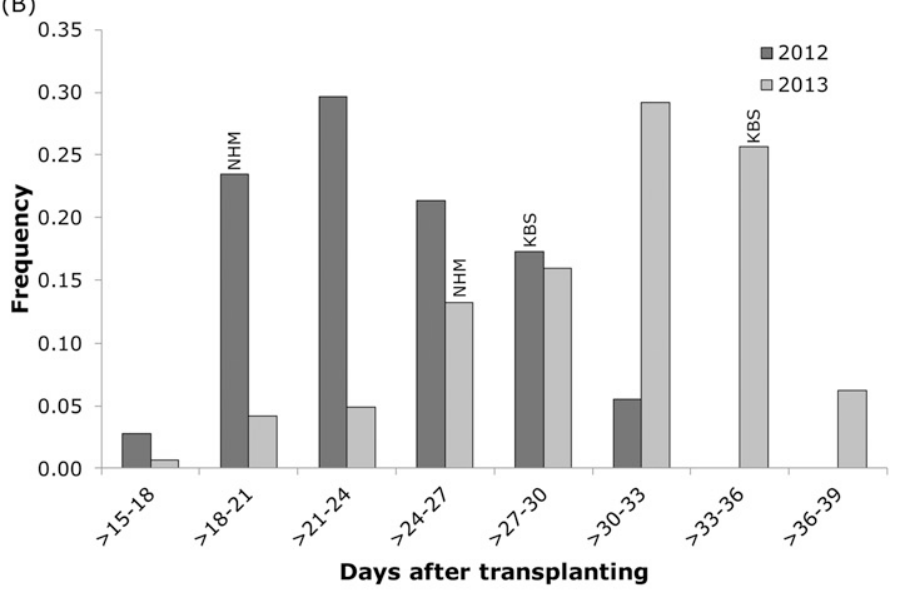

(C)

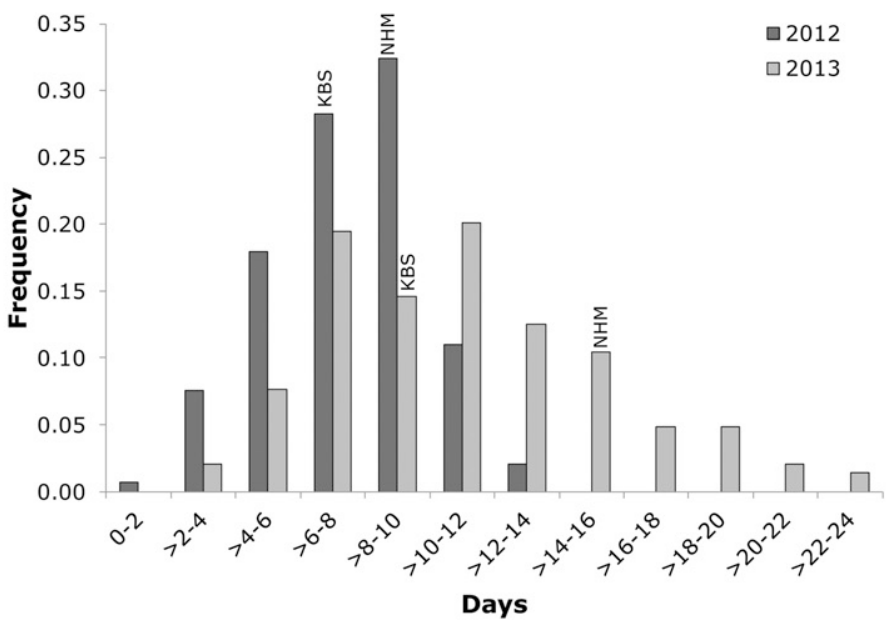

Fig. 1. Frequency distribution for (A) days to first open male flower, (B) days to first open female flower, and (C) female-male interval for $2012(\mathrm{n}=145)$ and $2013(\mathrm{n}=144)$ in the 'Klondike Black Seeded' (KBS) $\times$ 'New Hampshire Midget' (NHM) watermelon recombinant inbred line population as well the parental phenotypes.

known about the control of flowering time in this monoecious crop. Commercial cultivars are day-neutral (George, 2009) and male flowers usually open first, followed by female flowers at a ratio of roughly 7:1 (Wehner, 2008). The interval between the opening of the first male flower and first female flower is dependent on the cultivar and environmental conditions.

The percentage of watermelon production in the United States devoted to seedless fruit has increased dramatically from 51\% in 2003 to reach $85 \%$ in 2009 (U.S. Department of Agriculture, 2011). The seedless fruit is produced on triploid plants, but because pollination is required for fruit set and these plants produce negligible amounts of viable pollen, diploid pollen sources (pollenizers) are required (Boyhan et al., 2000; Maynard, 1992; Maynard and Elmstrom, 1992). As a result of this local preference for seedless fruit, U.S. watermelon production is dependent on synchronized flowering of diploid pollenizers and triploid watermelon cultivars for fruit production. However, the number of genes involved, mode of inheritance, heritability, and the possible candidate genes are all unknown for this crop. These factors are critical impediments to efficient breeding of watermelon cultivars in a changing environment, and especially for the United States where fruit production is dependent on synchronized flowering between two cultivars (a triploid and a pollenizer).

Recently, molecular tools have become available for watermelon that can now be used to advance breeding efforts. We recently produced the first single nucleotide polymorphism (SNP) maps for watermelon (Sandlin et al., 2012) and mapped the first QTL in the species (Prothro et al., 2012a, 2012b, 2013; Sandlin et al., 2012). In 2012, the draft watermelon genome sequence (Guo et al., 2013) became available and here we describe the use of these resources to elucidate the control of flowering time in watermelon.

\section{Materials and Methods}

Plant materials and genetic map. The 'Klondike Black Seeded' (KBS) $\times$ 'New Hampshire Midget' (NHM) recombinant inbred line (RIL) population developed previously to map QTL associated with fruit and seed traits (Prothro et al., 2012a; Sandlin et al., 2012) was advanced in the greenhouse (Jan. to Apr. 2012) through single seed descent (SSD) from $\mathrm{F}_{7}$ to $\mathrm{F}_{8}$ to generate seed for the current experiment.

Trait Phenotyping. During Summer 2012 and 2013, 150 RILs and parental cultivars were sown in seedling trays and transplanted $\approx 2$ weeks later on 23 May 2012 and 22 May 2013 at the Durham Horticulture Farm, in Watkinsville, GA. One plant per RIL/parental cultivar was planted per block in a completely randomized bock design with 10 blocks/replications. Plants were grown according to University of Georgia Cooperative Extension Service recommendations 
on plastic mulch with between-row spacing of $1.83 \mathrm{~m}$ and inrow spacing of $0.9 \mathrm{~m}$. In 2012, the vines were turned to make data collection easier, but, in 2013, high rainfall limited entry into the field to only days essential for data collection.

Data were collected three times per week for days to the opening of the first male flower, days to the opening of the first female flower, and subsequently calculated for female-male interval. Bisexual flowers were scored as female. Pearson correlations were calculated using JMP 9.0.2 (SAS Institute, Cary, NC).

Heritability on family-mean base was calculated as $h^{2}=\sigma_{\mathrm{G}}^{2} /$ $\left\{\left[\sigma^{2}{ }_{\mathrm{G}}+\left(\sigma^{2}{ }_{\mathrm{G} * \mathrm{Y}} / \mathrm{e}\right)+\left(\sigma^{2} \mathrm{e} / \mathrm{er}\right)\right]\right\}$ for the combined environments (Holland et al., 2003; Nyquist and Baker, 1991), where $\sigma^{2}{ }_{\mathrm{G}}$ equaled genetic variance among the entries, $\sigma^{2}{ }_{\mathrm{G}^{*} \mathrm{Y}}$ the variance of genetic $\times$ years interaction, $\sigma^{2}$ the variance of experimental error, e the number of years, and $r$ the number of replications. Because the data were unbalanced, e and $r$ were computed as harmonic mean of years and harmonic mean of total replications across all years, respectively (Holland et al., 2003).

QTL Detection. Composite interval mapping was used to identify QTL associate with the three traits using Model 6, a walk speed of $2 \mathrm{cM}$, and a window size of $5 \mathrm{cM}$ (Zeng, 1994; Zeng et al., 1999) with WinQTL Cartographer Version 2.5 (Wang et al., 2011). Data were analyzed separately for different years as well as jointly (averaged over years). Significance of the QTL was determined using 1000 permutations $(\alpha=0.05)$ (Churchill and Doerge, 1994; Doerge and Churchill, 1996)

Candidate Genes. The sequences of the SNP markers (Sandlin et al., 2012) closest to the QTL (Table 2) were used to determine the approximate location of the stable QTL on chromosome 3 of the draft genome sequence (Guo et al., 2013). The predicted genes in that region were then compared with genes known be involved in flowering time in other crops (Blackman et al., 2011; Ehrenreich et al., 2009; Jung et al., 2012; Matsoukas et al., 2012).

\section{Results and Discussion}

The average DMF for NHM and KBS was 9.4 and $21 \mathrm{~d}$, respectively, in 2012 and 11.7 and $25.8 \mathrm{~d}$ in 2013 (Fig. 1A). In 2012, the average DFF for NHM and KBS was 18.3 and 29.1 $\mathrm{d}$ and in 2013 it was 26.5 and $34.6 \mathrm{~d}$ (Fig. 1B). The FMI for the 2 years was 9.5 and $14.7 \mathrm{~d}$ for NHM and 7.1 and $8.5 \mathrm{~d}$ for KBS, respectively (Fig. 1C) with all traits showing some degree of transgressive segregation in the RIL population. There was a significant positive correlation between DMF and DFF within and across years and a significant negative correlation between DMF and MFI (Table 1). It appears that a larger MFI is associated with earlier male flowers rather than later female flowers, although there was also a significant negative correlation between $\mathrm{MFI}_{2013}$ and $\mathrm{DFF}_{2012}$ (but not $\mathrm{DFF}_{2013}$ ).

Generally, plants flowered later in $2013\left(\mathrm{DMF}_{\mathrm{avg}}=19.2 \mathrm{~d}\right.$, $\left.\mathrm{DFF}_{\mathrm{avg}}=30.3 \mathrm{~d}\right)$ than $2012\left(\mathrm{DMF}_{\mathrm{avg}}=16.1 \mathrm{~d}, \mathrm{DFF}_{\mathrm{avg}}=23.9 \mathrm{~d}\right)$ (Fig. 1A-B), probably as a result of the unusually high amount of rainfall in 2013. The total rainfall for the duration of this experiment was $98.3 \mathrm{~mm}$ in 2012 (10 rain days) and $292.9 \mathrm{~mm}$ in 2013 (21 rain days), whereas the average for this period from 2002 to 2011 was $137.1 \mathrm{~mm}$ with 14.5 rain days. DFF was more affected than DMF, leading to a higher FMI in 2013 (11.1 d) than $2012(7.7 \mathrm{~d})$, probably as a result of the timing of the high rainfall in the period from 11 to $27 \mathrm{~d}$ after transplanting $(69.3 \mathrm{~mm}$ in 2012 and $276.1 \mathrm{~mm}$ in 2013). Heritability for DMF, DFF, and MFI was $0.43 \pm 0.035,0.23 \pm 0.030$, and $0.10 \pm 0.022$,
Table 1. Pearson correlations for days to first male flower (DMF), days to first female flower (DFF) and male-female interval (FMI) for 2012 and 2013 in the 'Klondike Black Seeded' × 'New Hampshire Midget' watermelon recombinant inbred line population.

\begin{tabular}{lccccc}
\hline & 2012 & 2012 & 2012 & 2013 & 2013 \\
& DMF & DFF & FMI & DMF & DFF \\
\hline 2012 DFF & $0.79^{* * z}$ & & & & \\
2012 FMI & $-0.51^{* *}$ & 0.12 & & & \\
2013 DMF & $0.79 * *$ & $0.74 * *$ & $-0.24 *$ & & \\
2013 DFF & $0.57^{* *}$ & $0.68^{* *}$ & 0.05 & $0.67 * *$ & \\
2013 FMI & $-0.47^{* *}$ & $-0.28^{*}$ & $0.38^{* *}$ & $-0.65^{* *}$ & 0.131
\end{tabular}

z**, * Significant correlations at $P<0.0001$ and $P<0.01$, respectively.

respectively. This is much lower than what has been observed for days to male flowering $\left(\mathrm{h}^{2}=0.84\right)$, days to female flowering $\left(\mathrm{h}^{2}=0.83\right)$, and anthesis-silking interval $\left(\mathrm{h}^{2}=0.68\right)$ in the highly replicated maize (Zea maize) populations described by Buckler et al. (2009). In melon (Cucumis melo), heritability of days to anthesis (DA) of 0.64 (Zalapa et al., 2008) has been reported. However, it should be noted that in the latter study DA was defined as the time from transplanting to the time when $50 \%$ of plants were flowering rather than the individual plant basis of the current study.

Three QTL were associated with DMF in 2012 and one in 2013, whereas two QTL were identified for DFF and one for MFI in the 2 years (Table 2; Fig. 2). A major QTL for DMF $(Q d m f 3-1)$ and DFF (Qdff3-1) located on chromosome 3 explained $\approx 50 \%$ of the phenotypic variance observed in the population and was stable across the 2 years (Table 2; Fig. 2). In 2013 a QTL for FMI (Qfmi3) was also detected in this region. Additional QTL for DMF (Qdmf3-2) and DFF (Qdff3-2) were identified on chromosome 3 in 2012 but were not colocalized. QTL for DMF (Qdmf2) and MFI (Qmfi2) in 2012 were identified at a similar position on chromosome 2 , but were not detected in 2013, whereas a QTL for DFF (Qdff11) was detected on chromosome 11 in 2013 but not in 2012. Joint analysis (averaged over years) detected the colocalized QTL on chromosomes 2 (Qdmf2 and Qfmi2) and 3 (Qdmf3-1, Qdff3-1, and Qfmi3).

Co-localization for QTL for flowering traits is common and has been observed in other species (Buckler et al., 2009). QTL mapping in other crops suggested that a small number of genes with large effects are associated with flowering time in selfpollinating crops (Cockram et al., 2007; Izawa et al., 2003; Wills and Burke, 2007), whereas in out-crossing crops like maize, flowering time is controlled by a large number of QTL with small additive effects (Buckler et al., 2009). Despite being an out-crossing crop, our results indicate oligogenic control of flowering time in domesticated watermelon. However, it should be noted that watermelon has high natural self-pollination rates, as reflected by the lack of inbreeding depression in the species (Kumar et al., 2013; Kumar and Wehner, 2010; Wehner, 2008). Major colocalized QTL were also found to be associated with days to male and female flower development in Cucurbita pepo (Esteras et al., 2012). It remains to be seen whether oligogenic control of flowering time holds true for wild relatives of these cultivated crops.

Favorable alleles (early flowering) at the major QTL (Qdmf3-1, Qdff3-1) are contributed by the early flowering parent NHM (Table 2). However, the favorable allele at $Q d m f 2$ is contributed by the late flowering KBS parent. This is not unexpected, because antagonistic additive effects are expected 
Table 2. Genomic regions associated with quantitative trait loci (QTL) for days to first male flower (DMF), days to first female flower (DFF), and male-female interval $(\mathrm{FMI})$ for $2012(\mathrm{n}=145)$ and $2013(\mathrm{n}=144)$ in the 'Klondike Black Seeded' $\times$ 'New Hampshire Midget' watermelon recombinant inbred line population.

\begin{tabular}{|c|c|c|c|c|c|c|c|c|c|}
\hline Trait & $\begin{array}{l}\text { Suggested } \\
\text { name }\end{array}$ & $\mathrm{Yr}$ & $\operatorname{Chr}(\mathrm{LG})^{\mathrm{z}}$ & $\begin{array}{l}\text { Position } \\
\text { (cM) }\end{array}$ & $\mathrm{LOD}^{\mathrm{y}}$ & $R^{2}(\%)^{\mathrm{x}}$ & $\begin{array}{l}\text { Additive } \\
\text { effect }^{w}\end{array}$ & $\begin{array}{l}\text { LOD-1 support } \\
\text { interval }(\mathrm{cM})^{\mathrm{v}}\end{array}$ & $\begin{array}{l}\text { LOD-1 support } \\
\text { interval }(\mathrm{cM})^{\mathrm{v}}\end{array}$ \\
\hline$\overline{\mathrm{DMF}}$ & $Q d m f 2$ & 2012 & $2(\lg 9)$ & 75.71 & 3.4 & 4.0 & -0.86 & 72.7 & 78.8 \\
\hline DMF & $Q d m f 3-1$ & 2012 & $3(\lg 11)$ & 8.21 & 25.7 & 47.5 & 2.93 & 8.1 & 9.6 \\
\hline DMF & Qdmf3-1 & 2013 & $3(\lg 11)$ & 9.21 & 33.2 & 61.8 & 4.51 & 8.2 & 9.6 \\
\hline DMF & $Q d m f 2$ & Joint & $2(\lg 9)$ & 76.71 & 5.8 & 6.1 & -1.21 & 72.5 & 79.5 \\
\hline DMF & $Q d m f 3-1$ & Joint & $3(\lg 11)$ & 8.21 & 35.4 & 61.0 & 3.74 & 8.0 & 9.2 \\
\hline DFF & Qdff3-2 & 2012 & $3(\lg 11)$ & 79.91 & 4.7 & 5.8 & 0.87 & 78.2 & 84.7 \\
\hline DFF & Qdff3-1 & 2013 & $3(\lg 11)$ & 9.21 & 17.5 & 39.1 & 2.75 & 8.1 & 10.7 \\
\hline DFF & Qdff11 & 2013 & $11(\lg 3)$ & 106.21 & 4.0 & 6.9 & -1.15 & 103.7 & 113.5 \\
\hline DFF & Qdff3-1 & Joint & $3(\lg 11)$ & 9.21 & 22.3 & 44.7 & 2.53 & 8.1 & 10.4 \\
\hline FMI & Qfmi2 & 2012 & $2(\lg 9)$ & 75.71 & 4.3 & 10.7 & 0.84 & 66.5 & 73.6 \\
\hline
\end{tabular}

${ }^{\mathrm{z}}$ Chromosome (Guo et al., 2013; Ren et al., 2012) and linkage group (Sandlin et al., 2012).

${ }^{\mathrm{y}} \log _{10}$ likelihood ratio.

xPhenotypic variation explained.

"Negative values indicate that the effect is contributed by the allele from male parent.

${ }^{\mathrm{v}}$ Genomic region that includes QTL and flanking regions with LOD values larger than the QTL LOD minus 1.

Chr_2

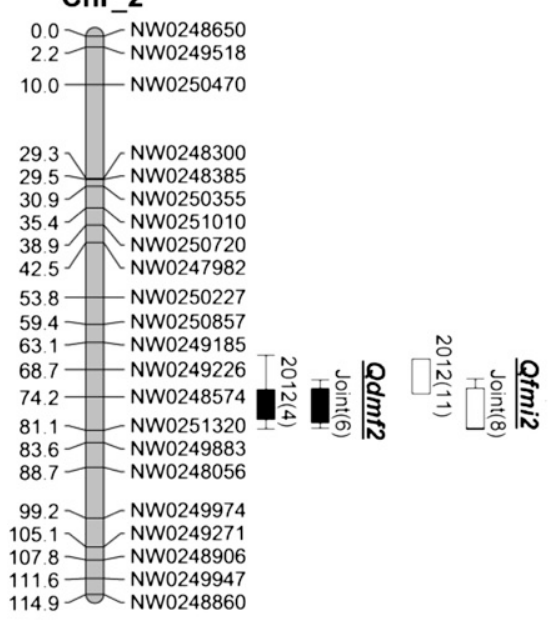

Chr_3

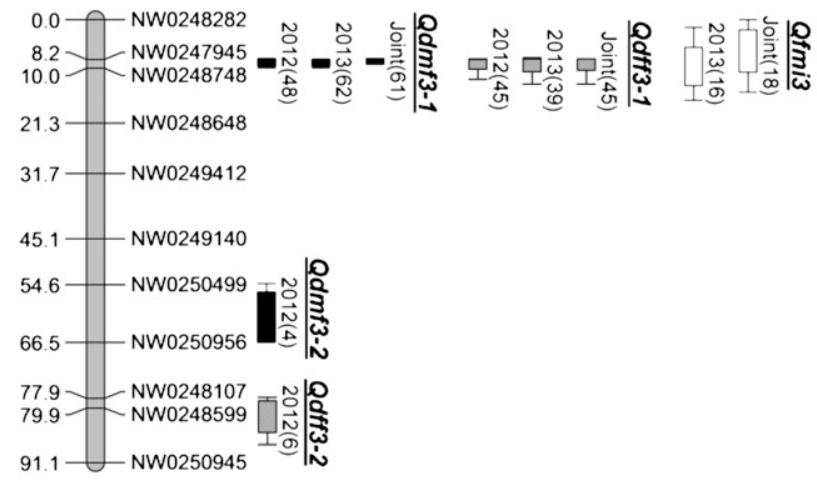

Chr_11

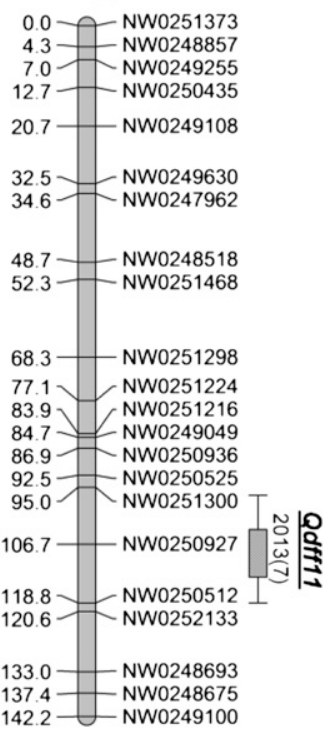

Fig. 2. Quantitative trait loci (QTL) identified for days to first open male flower (black box), days to first open female flower (gray box), and female-male interval (white box) for 2012, 2013, and joint data in the 'Klondike Black Seeded' $\times$ 'New Hampshire Midget' watermelon recombinant inbred line population. CentiMorgans are given on the left of the chromosomes $(\mathrm{Chr})$ and the length of the box and whiskers represent the LOD-1 and LOD-2 support interval for the QTL, respectively. The suggested name for each QTL is underlined, whereas the number in parentheses is the approximate percentage of phenotypic variance explained by the particular QTL. The figure was produced using MapChart Version 2.1 (Voorrips, 2002).

for traits with transgressive segregation (deVicente and Tanksley, 1993; Rieseberg et al., 1999).

The LOD-1.5 support interval [ $\approx 95 \%$ confidence interval (Silva et al., 2012)] for the major QTL on chromosome 3 stretches from 8.2 to $12 \mathrm{cM}$, which corresponds to approximately the 12.0 to $17 \mathrm{Mbp}$ region on chromosome 3 of the watermelon draft genome (Guo et al., 2013). This region contains 172 predicted genes, including Cla009504, a homolog of FT in squash [Cucurbita moschata,Cm_FTL2 (Lin et al., 2007)] and rice [Oryza sativa,
Hd3a (Kojima et al., 2002)] and Cla000855, an AP2/ERF and B3 domain-containing transcription factor with homology to TEM1 in A. thaliana (Castillejo and Pelaz, 2008). Expression of Cm_FTL2 and Hd3a in A. thaliana lead to earlier flowering (Kojima et al., 2002; Lin et al., 2007), whereas TEM1 is a repressor of FT and thus up-regulation of TEMI leads to delayed flowering (Castillejo and Pelaz, 2008; Osnato et al., 2012). TEM1 also regulates genes associated with gibberellin biosynthesis and thus connects the latter to the photoperiod 
pathway (Osnato et al., 2012). Cla009504 and Cla000855 represent excellent candidate genes toward the development of functional markers (Andersen and Lübberstedt, 2003) for marker-assisted selection (MAS) for flowering time in watermelon. We are currently sequencing the Cla009504 and Cla000855 alleles in this population and examining gene expression in early and late flowering genotypes. Flowering time traits are the target for MAS in several economically important crops including maize (Ducrocq et al., 2009), canola [Brassica napus (Raman et al., 2013)], soybean [Glycine max (Zhang et al., 2013)], rice (Yano et al., 2001), and wheat [Triticum aestivum (Yan et al., 2006)]. Functional markers, where the genotypic sequence used for selection is the cause of the phenotype, is the preferred marker type because there is no recombination between the marker and the trait gene (Andersen and Lübberstedt, 2003).

To ensure the broad applicability of any developed markers, future research needs to validate the stability of the QTL in multiple environments. During the RIL population seed increase through SSD in the greenhouse, data were also collected for DMF and DFF. Although this was under artificial light (14 h light/10 h dark) in the greenhouse and each line was represented by only a single plant, the major QTL on chromosome 3 (Qdmf3-1 and $Q d f f 3-1)$ were associated with flowering time $\left[\mathrm{DMF}_{\mathrm{GH}}-\mathrm{LOD}=26.1, \mathrm{DMF}_{\mathrm{GH}}-R^{2}=50 \%, \mathrm{DFF}_{\mathrm{GH}}-\mathrm{LOD}=14.0\right.$, $\mathrm{DFF}_{\mathrm{GH}}-R^{2}=28 \%$ (data not shown)]. This suggests that this QTL will have broad applicability in MAS for flowering time in watermelon.

Other aspects that need to be addressed in future research are the duration and consistency of flowering. These are critical traits in breeding for synchronized flowering where consistent pollen availability from pollenizers at the time when female triploid flowers are receptive, is essential.

Seedless watermelon production has unique challenges that require innovative solutions that will move the science of watermelon breeding forward. We identified a major, stable QTL associated with flowering time in watermelon, which gives us insight into the genetic architecture of this economically important trait. In addition, we identified candidate genes for further study toward elucidation of flowering time pathways and MAS that will reduce the breeding cycle of watermelon cultivars.

\section{Literature Cited}

Abe, M., Y. Kobayashi, S. Yamamoto, Y. Daimon, A. Yamaguchi, and Y. Ikeda. 2005. FD, a bZIP protein mediating signals from the floral pathway integrator FT at the shoot apex. Science 309:1052-1056.

Andersen, J.R. and T. Lübberstedt. 2003. Functional markers in plants. Trends Plant Sci. 8:554-560.

Blackman, B.K., D.A. Rasmussen, J.L. Strasburg, A.R. Raduski, J.M. Burke, S.J. Knapp, S.D. Michaels, and L.H. Rieseberg. 2011. Contributions of flowering time genes to sunflower domestication and improvement. Genetics 187:271-287.

Bolaños, J. and G.O. Edmeades. 1993. Eight cycles of selection for drought tolerance in lowland tropical maize. I. Responses in grain yield, biomass, and radiation utilization. Field Crops Res. 31:233252.

Boyhan, G.E., D.M. Granberry, and T.W. Kelley. 2000. Commercial watermelon production. Univ. Georgia Coop. Ext. Serv. Bul. 996.

Buckler, E.S., J.B. Holland, P.J. Bradbury, C.B. Acharya, P.J. Brown, C. Browne, E. Ersoz, S. Flint-Garcia, A. Garcia, J.C. Glaubitz, M.M. Goodman, C. Harjes, K. Guill, D.E. Kroon, S. Larsson, N.K. Lepak, H. Li, S.E. Mitchell, G. Pressoir, J.A. Peiffer, M.O. Rosas, T.R. Rocheford, M.C. Romay, S. Romero, S. Salvo, H.S. Villeda, H. Sofia da Silva, Q. Sun, F. Tian, N. Upadyayula, D. Ware, H. Yates, J. Yu, Z. Zhang, S. Kresovich, and M.D. McMullen. 2009. The genetic architecture of maize flowering time. Science 325:714-718.

Castillejo, C. and S. Pelaz. 2008. The balance between CONSTANS and TEMPRANILLO activities determines FT expression to trigger flowering. Curr. Biol. 18:1338-1343.

Chapman, S.C. and G.O. Edmeades. 1999. Selection improves drought tolerance in tropical maize populations. II. Direct and correlated changes among secondary traits. Crop Sci. 39:1315-1324.

Churchill, G.A. and R.W. Doerge. 1994. Empirical threshold values for quantitative trait mapping. Genetics 138:963-971.

Cockram, J., H. Jones, F.J. Leigh, D. O'Sullivan, W. Powell, D.A. Laurie, and A.J. Greenland. 2007. Control of flowering time in temperate cereals: Genes, domestication, and sustainable productivity. J. Expt. Bot. 58:1231-1244.

Craufurd, P.Q. and T.R. Wheeler. 2009. Climate change and the flowering time of annual crops. J. Expt. Bot. 60:2529-2539.

deVicente, M.C. and S.D. Tanksley. 1993. QTL analysis of transgressive segregation in an interspecific tomato cross. Genetics 134:585-596.

Doerge, R.W. and G.A. Churchill. 1996. Permutation tests for multiple loci affecting a quantitative character. Genet. Mol. Biol. 142:285-294. Ducrocq, S., C. Giauffret, D. Madur, V. Combes, F. Dumas, S. Jouanne, D. Coubriche, P. Jamin, L. Moreau, and A. Charcosset. 2009. Fine mapping and haplotype structure analysis of a major flowering time quantitative trait locus on maize chromosome 10. Genetics 183:1555-1563.

Ducrocq, S., D. Madur, J.-B. Veyrieras, L. Camus-Kulandaivelu, M. Kloiber-Maitz, T. Presterl, M. Ouzunova, D. Manicacci, and A. Charcosset. 2008. Key impact of Vgt1 on flowering time adaptation in maize: Evidence from association mapping and ecogeographical information. Genetics 178:2433-2437.

Ehrenreich, I.M., Y. Hanzawa, L. Chou, J.L. Roe, P.X. Kover, and M.D. Purugganan. 2009. Candidate gene association mapping of Arabidopsis flowering time. Genetics 183:325-335.

Esteras, C., P. Gomez, A.J. Monforte, J. Blanca, N. Vicente-Dolera, C. Roig, F. Nuez, and B. Pico. 2012. High-throughput SNP genotyping in Cucurbita pepo for map construction and quantitative trait loci mapping. BMC Genomics 13:80.

Food and Agriculture Organization of the United Nations. 2011. Crop production 2010. 14 Jan. 2013. <http://faostat.fao.org/site/567/ default.aspx\#ancor>.

George, R.A.T. 2009. Vegetable seed production. CABI, Cambridge, MA. Guo, S., J. Zhang, H. Sun, J. Salse, W.J. Lucas, H. Zhang, Y. Zheng, L. Mao, Y. Ren, Z. Wang, J. Min, X. Guo, F. Murat, B.-K. Ham, Z. Zhang, S. Gao, M. Huang, Y. Xu, S. Zhong, A. Bombarely, L.A. Mueller, H. Zhao, H. He, Y. Zhang, Z. Zhang, S. Huang, T. Tan, E. Pang, K. Lin, Q. Hu, H. Kuang, P. Ni, B. Wang, J. Liu, Q. Kou, W. Hou, X. Zou, J. Jiang, G. Gong, K. Klee, H. Schoof, Y. Huang, X. Hu, S. Dong, D. Liang, J. Wang, K. Wu, Y. Xia, X. Zhao, Z. Zheng, M. Xing, X. Liang, B. Huang, T. Lv, J. Wang, Y. Yin, H. Yi, R. Li, M. Wu, A. Levi, X. Zhang, J.J. Giovannoni, J. Wang, Y. Li, Z. Fei, and Y. Xu. 2013. The draft genome of watermelon (Citrullus lanatus) and resequencing of 20 diverse accessions. Nat. Genet. 45:51-58.

Holland, J.B., W.E. Nyquist, and C.T. Cervantes-Martinez. 2003. Estimating and interpreting heritability for plant breeding: An update. Plant Breed. Rev. 22:9-111.

Izawa, T., Y. Takahashi, and M. Yano. 2003. Comparative biology comes into bloom: Genomic and genetic comparison of flowering pathways in rice and Arabidopsis. Curr. Opin. Plant Biol. 6:113-120. Jackson, S.D. 2009. Plant responses to photoperiod. New Phytol. 181:517-531.

Jung, C. and A.E. Müller. 2009. Flowering time control and applications in plant breeding. Trends Plant Sci. 14:563-573.

Jung, C.-H., C.E. Wong, M.B. Singh, and P.L. Bhalla. 2012. Comparative genomic analysis of soybean flowering genes. PLoS One 7:e38250. 
Kardailsky, I., V.K. Shukla, J.H. Ahn, N. Dagenais, S.K. Christensen, J.T. Nguyen, J. Chory, M.J. Harrison, and D. Weigel. 1999. Activation tagging of the floral inducer FT. Science 286:1962-1965. Kobayashi, Y., H. Kaya, K. Goto, M. Iwabuchi, and T. Araki. 1999. A pair of related genes with antagonistic roles in mediating flowering signals. Science 286:1960-1962.

Kojima, S., Y. Takahashi, Y. Kobayashi, L. Monna, T. Sasaki, T. Araki, and M. Yano. 2002. Hd3a, a rice ortholog of the Arabidopsis FT gene, promotes transition to flowering downstream of $H d l$ under short-day conditions. Plant Cell Physiol. 43:1096-1105.

Kumar, R., M. Dia, and T.C. Wehner. 2013. Implications of mating behavior in watermelon breeding. HortScience 48:960-964.

Kumar, R. and T. Wehner. 2010. Natural outcrossing in watermelon-A review. Cucurbit Genet. Coop. Rpt. 33/34:42-43.

Lee, J., M. Oh, H. Park, and I. Lee. 2008. SOC1 translocated to the nucleus by interaction with AGL24 directly regulates LEAFY. Plant J. 55:832-843.

Lin, M.-K., H. Belanger, Y.-J. Lee, E. Varkonyi-Gasic, K.-I. Taoka, E. Miura, B. Xoconostle-Cázares, K. Gendler, R.A. Jorgensen, B. Phinney, T.J. Lough, and W.J. Lucas. 2007. FLOWERING LOCUS T protein may act as the long-distance florigenic signal in the cucurbits. Plant Cell 19:1488-1506.

Liu, C., H. Chen, H.L. Er, H.M. Soo, P.P. Kumar, and J.H.E.A. Han. 2008. Direct interaction of AGL24 and SOC1 integrates flowering signals in Arabidopsis. Dev. Change 135:1481-1491.

Matsoukas, I.G., A.J. Massiah, and B. Thomas. 2012. Florigenic and antiflorigenic signaling in plants. Plant Cell Physiol. 53:18271842.

Maynard, D.N. 1992. Growing seedless watermelon. Univ. Florida. Coop. Ext. Serv. Fact Sheet HS687.

Maynard, D.N. and G.W. Elmstrom. 1992. Triploid watermelon production practices and cultivars. Acta Hort. 318:169-173.

Melzer, S., F. Lens, J. Gennen, S. Vanneste, A. Rohde, and T. Beeckman. 2008. Flowering-time genes modulate meristem determinacy and growth form in Arabidopsis thaliana. Nat. Genet. 40:1489-1492.

Nyquist, W.E. and R. Baker. 1991. Estimation of heritability and prediction of selection response in plant populations. Crit. Rev. Plant Sci. 10:235-322.

Osnato, M., C. Castillejo, L. Matías-Hernández, and S. Pelaz. 2012. TEMPRANILLO genes link photoperiod and gibberellin pathways to control flowering in Arabidopsis. Nature Commun. 3:808.

Poland, J.A., P.J. Balint-Kurti, R.J. Wisser, R.C. Pratt, and R.J. Nelson. 2009. Shades of gray: The world of quantitative disease resistance. Trends Plant Sci. 14:21-29.

Prothro, J., H. Abdel-Haleem, E. Bachlava, C. White, S. Knapp, and C. McGregor. 2013. Quantitative trait loci associated with sex expression in an inter-subspecific watermelon population. J. Amer. Soc. Hort. Sci. 38:125-130.

Prothro, J., K. Sandlin, H. Abdel-Haleem, E. Bachlava, W. White, S. Knapp, and C. McGregor. 2012a. Main and epistatic quantitative trait loci associated with seed size in watermelon. J. Amer. Soc. Hort. Sci. 137:452-457.

Prothro, J., K. Sandlin, R. Gill, E. Bachlava, V. White, S. Knapp, and C. McGregor. 2012b. Mapping of the egusi seed trait locus (eg) and quantitative trait loci associated with seed oil percentage in watermelon. J. Amer. Soc. Hort. Sci. 137:311-315.

Raman, H., R. Raman, P. Eckermann, N. Coombes, S. Manoli, X. Zou, D. Edwards, J. Meng, R. Prangnell, J. Stiller, J. Batley, D. Luckett, N. Wratten, and E. Dennis. 2013. Genetic and physical mapping of flowering time loci in canola (Brassica napus L.). Theor. Appl. Genet. 126:119-132.

Ren, Y., H. Zhao, Q. Kou, J. Jiang, S. Guo, H. Zhang, W. Hou, X. Zou, H. Sun, G. Gong, A. Levi, and Y. Xu. 2012. A high resolution genetic map anchoring scaffolds of the sequenced watermelon genome. PLoS One 7:e29453.

Richards, R.A. 2006. Physiological traits used in the breeding of new cultivars for water-scarce environments. Agr. Water Mgt. 80:197-211.

Rieseberg, L.H., M.A. Archer, and R.K. Wayne. 1999. Transgressive segregation, adaptation and speciation. Heredity 83:363-372.

Sandlin, K.C., J.M. Prothro, A.F. Heesacker, N. Khalilian, R. Okashah, W. Xiang, E. Bachlava, D. Caldwell, D. Seymour, V. White, E. Chan, G. Tolla, C. White, D. Safran, E. Graham, S.J. Knapp, and C.E. McGregor. 2012. Comparative mapping in watermelon [Citrullus lanatus (Thunb.) Matsum. et Nakai]. Theor. Appl. Genet. 125:16031618.

Siddique, K.H.M., D. Tennant, M.W. Perry, and R.K. Belford. 1990. Water use and water use efficiency of old and modern wheat cultivars in a Mediterranean-type environment. Aust. J. Agr. Res. 41:431-447.

Silva, L.D., S. Wang, and Z.-B. Zeng. 2012. Composite interval mapping and multiple interval mapping: Procedures and guidelines for using windows QTL Cartographer. Quantitative trait loci (QTL). Methods Protocols 871:75-119.

Turck, F., F. Fornara, and G. Coupland. 2008. Regulation and identity of florigen: FLOWERING LOCUS T moves center stage. Annu. Rev. Plant Biol. 59:573-594.

U.S. Department of Agriculture. 2011. U.S. Department of Agriculture - National Agricultural Statistics Service. Agricultural statistics. 16 Jan. 2013. <http://www.nass.usda.gov/Publications/Ag_Statistics/ index.asp $>$.

Valverde, F., A. Mouradov, W. Soppe, D. Ravenscroft, A. Samach, and G. Coupland. 2004. Photoreceptor regulation of CONSTANS protein in photoperiodic flowering. Science 303:1003-1006.

Voorrips, R.E. 2002. MapChart: Software for the graphical presentation of linkage maps and QTLs. J. Hered. 93:77-78.

Wang, S., C.J. Basten, and Z.B. Zeng. 2011. Windows QTL Cartographer 2.5. Dept. Statistics, North Carolina State Univ., Raleigh, NC. Wehner, T. 2008. Watermelon, p. 381-418. In: Prohens, J. and F. Nuez (eds.). Vegetables I: Asteraceae, Brassicaceae, Chenopodicaceae, and Cucurbitaceae. Springer, New York, NY.

Wigge, P.A., M.C. Kim, K.E. Jaeger, W. Busch, M. Schmid, and J.U. Lohmann. 2005. Integration of spatial and temporal information during floral induction in Arabidopsis. Science 309:1056-1059.

Wills, D.M. and J.M. Burke. 2007. Quantitative trait locus analysis of the early domestication of sunflower. Genetics 176:2589-2599.

Yan, L., D. Fu, C. Li, A. Blechl, G. Tranquilli, M. Bonafede, A. Sanchez, M. Valarik, S. Yasuda, and J. Dubcovsky. 2006. The wheat and barley vernalization gene VRN3 is an orthologue of FT. Proc. Natl. Acad. Sci. USA 103:19581-19586.

Yano, M., S. Kojima, Y. Takahashi, H. Lin, and T. Sasaki. 2001. Genetic control of flowering time in rice, a short-day plant. Plant Physiol. 127:1425-1429.

Yoo, S.K., K.S. Chung, J. Kim, J.H. Lee, and S.M. Hong. 2005. CONSTANS activates SUPPRESSOR OF OVEREXPRESSION OF CONSTANS 1 through FLOWERING LOCUS T to promote flowering in Arabidopsis. Plant Physiol. 139:770-778.

Zalapa, J., J. Staub, and J.D. McCreight. 2008. Variance component analysis of plant architectural traits and fruit yield in melon. Euphytica 162:129-143.

Zeng, Z.B. 1994. Precision mapping of quantitative trait loci. Genetics 136:1457-1468.

Zeng, Z.B., C.H. Kao, and C.J. Basten. 1999. Estimating the genetic architecture of quantitative traits. Genet. Res. 74:279-289.

Zhang, D., H. Cheng, Z. Hu, H. Wang, G. Kan, C. Liu, and D. Yu. 2013. Fine mapping of a major flowering time QTL on soybean chromosome 6 combining linkage and association analysis. Euphytica 191:23-33. 